\title{
Prognoser i \\ tvångsvårdsärenden om \\ omsorgssvikt
}

\author{
KATARINA ALEXIUS
}

\begin{abstract}
I barnavårdsärenden är det ibland centralt hur nu- och dåtid kopplas till en prognos baserad på kunskaper om risker. I denna artikel undersöks relationen mellan bakgrunds-, prognos- och kunskapspåståenden i utredningar och domar som rör tvångsomhändertaganden till följd av brister i omsorgen om barn i familjer där någon förälder har kognitiv funktionsnedsättning.
\end{abstract}

\section{Inledning $^{1}$}

Om ett barns vårdbehov inte kan tillgodoses i samarbete med berörd familj i enlighet med socialtjänstlagen ska barnet, om det är i enlighet med dess bästa, tvångsvårdas med stöd av lagen med särskilda bestämmelser om vård av unga; LVU. Av $2 \S \mathrm{LVU}$, som rör miljöfall, följer att tvångsvård ska "beslutas om det på grund av fysisk eller psykisk misshandel, otillbörligt utnyttjande, brister i omsorgen eller något annat förhållande i hemmet finns en påtaglig risk

Katarina Alexius, docent, institutionen för socialt arbete, Stockholms universitet. för att den unges hälsa eller utveckling skadas". En tillämpningsstudie visar att i ärenden enligt nyssnämnda bestämmelse åberopas vanligen "brister i omsorgen" i ungefär 70 procent av fallen som enda grund och i ungefär 15 procent av fallen $\mathrm{i}$ kombination med misshandel (Socialstyrelsen 2009).

1 Artikeln är en del av forskningsprojektet "Barns behov och föräldrars (o)förmåga. En studie av vårdbehovsbedömningar i mål om tvångsvård av barn till utvecklingsstörda föräldrar", som har finansierats genom generösa bidrag från Stiftelsen Sävstaholm samt från Torsten och Ragnar Söderbergs stiftelser. 
Bedömningen av negativa miljöfaktorer sker utifrån ett tillbakablickande perspektiv. Bedömningen av "påtaglig risk" innefattar däremot en prognos om barnets framtid. En central fråga i en del barnavårdsutredningar är därför i vilken utsträckning som bakgrundspåståenden om nu- och dåtid kan läggas till grund för en förutsägelse om risk på individnivå i framtiden. Sådana prognoser måste för att framstå som logiska och trovärdiga grundas på kunskaper om barns behov och om risker i barns uppväxtvillkor (Lagerberg \& Sundelin 2000). I denna artikel studeras sociala utredningar och domar som rör tvångsomhändertaganden till följd av omsorgsbrister av barn i familjer där någon förälder har kognitiv funktionsnedsättning. Artikelns syfte är att genom en kvalitativ innehållsanalys undersöka relationen mellan bakgrunds-, prognos- och kunskapspåståenden i de studerade texterna.

\section{Urval}

För att klarlägga relationen mellan bakgrunds- , prognos- och kunskapspåståenden i tvångsvårdsärenden undersöktes texter där det var sannolikt att bedömningarna präglas av en viss komplexitet. Både svenska och internationella studier visar att familjer där någon förälder har kognitiv funktionsnedsättning vanligen är av strukturella skäl bidragsberoende, har förhöjd risk för hälsoproblem av olika sort samt är proportionellt sett överrepresenterade i ärenden om tvångsomhändertagande av barn (Alexius \& Hollander 2014; Hollander 1985; Llewellyn et al 2003; McConnell et al
2011; McGaw et al 2010). Det kan i ärenden om tvångsvård av barn i sådana familjer ibland antas uppstå spänningar mellan barns behov utifrån ett barnperspektiv och funktionsnedsattas rätt till familjeliv ur ett likabehandlingsperspektiv (Alexius 2011). Eftersom offentliga institutioner omfattas av objektivitetsprincipen ska sociala utredningar och domar baseras på sakliga och logiskt underbyggda bedömningar. Urvalet består därför av utredningar och domar enligt $2 \S L V U$ i domsarkiven i två län under en kammarrätt år 2009 i alla ärenden där en eller båda föräldrarna beskrivs ha intellektuell funktionsnedsättning. ${ }^{2}$

Det undersökta textmaterialet rör 16 familjer, som omfattar 29 barn och 30 vuxna. Familjerna har givits beteckningarna A-P och personnamn har i citaten ersatts av "barnet", "modern" och "fadern". För att undvika möjligheterna till så kallad bakvägsidentifikation finns ingen tabell eller motsvarande över familjer och familjemedlemmar i relation till ärendehanteringen. Av samma skäl undviks i huvudsak sammanföranden av offentliga texter i form av domar med sekretessbelagt material i form av sociala utredningar.

Alla utredningarna är utformade efter

2 Urvalet avser ärenden där minst en vårdnadshavare i länsrättsdomen antingen anges ha diagnosen intellektuell funktionsnedsättning eller beskrivs ha kognitiva svårigheter med påtagliga adaptiva begränsningar och som även har motsatt sig att få eventuell problematik utredd. Urvalsmetoden innebär att det kan finnas ett mindre bortfall av ärenden, där det inte framgår av vare sig parternas talan eller domskälen att någon eller båda vårdnadshavarna tycks ha en intellektuell funktionsnedsättning. 
utredningsmodellen BBIC, som enligt Socialstyrelsen (2006) baseras på bland annat utvecklingsekologi, anknytningsteori samt kunskaper om barns motståndskraft och samspelet mellan risk- och skyddsfaktorer. BBIC-modellen är uppbyggd så att behovsoch riskbedömningar ska grundas på klarlägganden av barnets behov, av föräldrarnas förmåga samt av andra familje- och miljöfaktorer. I samtliga här studerade 29 utredningar åberopar socialtjänsten att det förekommer brister i omsorgen, i vissa fall i kombination med andra grunder för tvångsomhändertagande. I de 16 underrättsdomarna bifölls alla ansökningar om tvångsvård. Inget av de 11 fallen av överklagande till kammarrätten föranledde ändring. I citaten redovisas utredningarna som "Utr", underinstansdomar som "Lr" och kammarrättsdomar som "Kr".

\section{Perspektiv på metoden}

Lagstiftningen om tvångsvård av barn har uttalat intervenerande och beteendestyrande syften (Mattsson 2002). Sociala utredningar och domar har i denna undersökning därför studerats utifrån uppfattningen att rättsreglernas föreställningsinnehåll fungerar handlingsdirigerande och alltså påverkar beslutsfattares faktiska handlande (Peczenik 1995; Stjernquist \& Widerberg 1989). Texter i utredningar och domar granskas därmed så att lagstiftningens rättsdogmatiska innehåll undersöks i förhållande till dess faktiska tillämpning. Eftersom tidigare undersökningar visar att bedömningar i barnavårdsärenden av å ena sidan socialtjänsten och å andra sidan domstolar baseras på skilda kompetensoch professionskontexter är det relevant att studera samma ärenden på olika rättsliga nivåer (Hollander 1985; Jacobson 2006; Ponnert 2007). Även om det förekommer att kammarrättsdomar ges visst prejudikatvärde undersöks dessa domar här endast som en del i ett empiriskt material.

Det unika i varje text, helheten i fallen och i det samlade textmaterialet om totalt 56 olika texter, har tolkats genom en kvalitativ innehållsanalys (Bergström \& Boreus 2005; Watt Bolsen 2007). Tillvägagångssättet har inneburit att bakgrunds-, prognosoch kunskapspåståenden har identifierats och kodats. Därefter har de olika påståendenas innehåll och inbördes relation undersökts (Alexius 2011; Diesen \& Veloz Roca 2003). Bakgrundspåståenden är beskrivningar av fakta och omständigheter i nuoch dåtid i det enskilda fallet, medan prognospåståenden är utsagor om framtiden i det enskilda fallet. Med kunskapspåståenden avses utsagor om empiriskt belagda generella förhållanden eller generaliserande teoretiska förklaringsmodeller. ${ }^{3}$

\section{Att som barn ha bevittnat vaild inom famil-} jen kan medföra långvariga psykiska problem som depressivitet, ångest, självdestruktivitet och aggressivitet (kunskaps-

3 Kunskapspåståenden är alltså detsamma som det som inom processrätten kallas erfarenhetssatser, det vill säga påståenden om empiriska kunskaper, som härrör från antingen allmänbildning och livserfarenhet; s.k. allmänna erfarenhetssatser, eller tillförs i det särskilda fallet genom professionsbaserade expertbedömningar; s.k. särskilda erfarenhetssatser (Alexius 2011; Diesen \& Veloz Roca 2003; Kaldal 2010). 
påstående). Barnet har inte fätt sitt behov av trygghet, värme och tillgänglighet tillgodosett $i$ hemmet och har tvingats bevittna vaild gentemot modern samt sin äldre syster (bakgrundspåstående). Hon behöver beredas vård eftersom det på grund av brister $i$ omsorgen om henne finns en pataglig risk för att hennes hälsa och utveckling skadas (prognospåstående). (Utr-H)

En nackdel med textanalys är att texter och inte aktörernas egentliga beteenden och tankar studeras. Dessutom kan maktförhållanden mellan myndigheter och enskilda döljas i texterna, som ju formuleras av myndighetsrepresentanter. Sociala utredningar och domar utgör emellertid dokumentation av offentligt beslutsfattande. Förekomsten av inre koherent logik i sådana textmaterial är central både för enskildas rättssäkerhet och för den offentliga maktens trovärdighet. Genom klarläggande av relationen mellan bakgrunds-, prognos- och kunskapspåståenden åskådliggörs i här studerat material den faktiska rättstillämpningen med god pragmatisk validitet i förhållande till det rättsdogmatiska perspektivet. Eftersom urvalet baseras på en specifik sorts ärenden är resultatet analytiskt generaliserbart främst för fall av tvångsvård till följd av omsorgssvikt av barn i familjer där det finns kognitiv nedsättning hos någon av föräldrarna.

\section{Bakgrund och kort om tidigare forskning}

Enligt proportionalitetsprincipen i 2 kap. 21 § regeringsformen (1974:152) ska tvångsåtgärder användas restriktivt och aldrig gå utöver vad som är nödvändigt med hänsyn till ändamålet med åtgärden. För att godtycklighet i mesta möjliga mån ska undvikas utformas tvångslagstiftning så tydligt som möjligt. Eftersom tvångsvård av barn sker utifrån behovs- och riskbedömningar är det emellertid svårt att åstadkomma en enhetlig och förutsebar tillämpning av rättsreglerna (Alexius \& Hollander 2014; Bramstång 1964; Friis 2003; Hollander 1985; Leviner 2011; Mattsson 2002; Ponnert 2007, Svensson 2011; Östberg 2010). Bedömningar av vårdbehov baseras i regel på socialvetenskapliga och medicinska analyser och domstolarna förlitar sig ofta på den professionsbaserade expertisens uppfattningar (Diesfeld \& Sjöström 2007; Hollander 1985; Jacobsson 2006; Mattsson 2002; McDonnell et al 2000).

Enligt lagförarbetena till LVU innebär en "påtaglig risk" att risken inte är obetydlig, oklar eller avlägsen, utan att det finns en klar och konkret risk för barnets hälsa eller utveckling (prop. 1989/90:28; prop. 2002/03: 53; SOU 2000:77). Uttrycket "påtaglig risk", som är väl belyst inom den juridiska doktrinen, anses innebära att beslut om tvångsvård ska grundas på en prognos om att ett visst barns hälsa eller utveckling med 70-75 procents sannolikhet kommer att skadas (Diesen \& Veloz Roca 2003; Kaldal 2010). I rättsfallet RÅ 1995 ref. 46, som rör ett barn till en ensamstående mamma med psykiska problem, menade Regeringsrätten, numera Högsta förvaltningsdomstolen, att "( $\mathrm{t}$ )idsaspekten i fråga om risken har emellertid inte kunnat anges och inte heller har storleken av risken" kunnat "preciseras närmare". Domstolen, 
som lämnade ansökan om tvångsvård utan bifall, anförde vidare att det i målet förelåg "betydande osäkerhet" beträffande både sannolikheten för skador hos barnet, hur allvarliga eventuella skador kunde tänkas bli och vid vilken tidpunkt som eventuella skador kunde väntas uppkomma. Likartade krav på konkretion av vari den "påtagliga risken" består har ställts i andra avgöranden av Högsta förvaltningsdomstolen (R 1995 ref. 64; RÅ 2009 ref. 64; jfr dock Svensson 2011).

Utifrån de krav som rättsdogmatiskt sett ställs, ska en ansökan om tvångsvård av barn alltså innehålla bakgrunds- , prognos- och kunskapspåståenden som tydliggör eller i vart fall belyser när en skada kan antas uppstå, graden av sannolikhet för skada samt hur allvarlig den eventuella skadan kan antas bli. Att lägga kunskapspåståenden om prediktion, det vill säga om statistisk risk på gruppnivå, till grund för prognoser i särskilda fall kan emellertid vara svårt. Samspelet mellan olika faktorer hos barn och i deras miljö är nämligen så komplext att det ibland är svårt att göra riskbedömningar med någon högre grad av precision (Alexius 2011; Backe-Hansen 2001; Claezon 1987; Gillingham 2009; Lagerberg \& Sundelin 2000; Leviner 2011; Lundström 2005; Lundström 2011; Munro 2008; Sundell et al. 2007; Svensson 2011). Förväntningar på att bedömningar av barns vårdbehov ska vara evidensbaserade i bemärkelsen grundade på vetenskap och tillämpning av belagt verkningsfulla interventioner kan därför inte alltid anses realistiska (jfr Bergmark et al 2011).

Kaldal (2010) menar att bedömningar av orsakssamband mellan omsorgssvikt och skador visserligen kan vara komplicerade, men att en del av Högsta förvaltningsdomstolens praxis ur ett barnskyddsperspektiv präglas av alltför stor restriktivitet. På ett likartat sätt noterar Leviner (2011, s. 282 och 315) att tvångsvård av barn i praktiken tycks aktualiseras främst "när skadan redan skett" och att det ibland anförs att "en orsak till att det inte går så bra för placerade barn kan vara att de faktiskt omhändertas för sent och att skadan därmed redan kan vara skedd”. Även Ponnert (2007) anför slutsatser i denna riktning.

\section{Resultat och analys}

\section{Relationen mellan bakgrunds- och prognospåståenden}

Bakgrundspåståenden genom beskrivningar av missförhållanden i nu- och dåtid dominerar både utredningstexterna och domarna. Länsrättsdomarna har dock ett väsentligt mer begränsat textomfång än utredningarna och kammarrättsdomarna är ännu mer kortfattade. Domskälen i de senare består i flertalet fall av instämmanden $\mathrm{i}$ underrättens bedömningar.

Vad modern och fadern har anfört och vad som $i$ övrigt kommit fram av utredningen $i$ målet föranleder inte kammarrätten att göra någon annan bedömning än som länsrätten gjort $i$ den överklagade domen. Överklagandena ska därför avslås. (Kr-D)

$\mathrm{Av}$ socialnämndens bakgrundspåståenden framgår att föräldrarna i sju fall är i 
huvudsak sammanboende, medan barnen i nio av familjerna bor hos modern. Samtliga familjer kan sägas ha multiproblem (Spratt 2009), bland annat genom att föräldrarna utöver kognitiva begränsningar har särskilda behov till följd av exempelvis nedsatt hörsel, ledbesvär eller olika typer av psykiatriska sjukdomstillstånd. Föräldrarnas socioekonomiska utsatthet är likartad som för familjer generellt i tvångsvårdsärenden, men framstår som mer påtaglig än för familjer i vanliga barnavårdsärenden (Hollander 1985; Östberg 2010).

I flertalet utredningar beskrivs familjerelationerna som kaotiska med exempel på långvariga konflikter mellan föräldrarna, social isolering och ekonomisk misär. Familjerna är kända av socialtjänsten sedan många år utom i två fall, där de har aktualiserats till följd av nu utrett barns födelse. Tidigare insatser har vanligen bestått av hemterapeut och kontaktfamilj för barnen.

Bristerna i föräldrarnas omsorgsförmåga relateras i samtliga utredningar i mindre eller större utsträckning till konsekvenserna för barnen av att den ena eller båda föräldrarna har kognitiva funktionsnedsättningar. I samtliga såväl utredningar som domar anses föräldrarna ha otillräckliga adaptiva utvecklingsmöjligheter för att i framtiden uppnå en tillfredställande omsorgsförmåga. Det är dock endast i tre (B, E, L) av de sexton ärendena som det uppges att föräldrarnas adaptiva förmåga och utvecklingsmöjligheter har undersökts med exempelvis PAM (Parent Assessment Manual) eller på annat sätt.

Modern har inte förmått identifiera sig själv som den vuxna i relationen till dottern och har därigenom lämnat över sitt föräldraansvar till dottern i flera avseenden. Modern har inte kunnat ta till sig kunskap kring barns behov och omsätta i praktik, trots täta samtal och träning anpassat efter moderns kognitiva svårigheter. (Utr-B, där PAM använts)

De 29 utredningarna är genomgående strukturerade så att texternas innehåll domineras av bakgrundspåståenden om missförhållanden som gör att barnets behov inte tillgodoses, följt av analys och bedömning där förekomsten av en "påtaglig risk" för barnets hälsa och utveckling slås fast. Prognoserna konstrueras i flertalet studerade texter genom beskrivningar av behov som barnen inte får tillgodosedda.

Till stöd för denna bedömning finns således långvariga och omfattande kunskaper om familjens förhällanden och det kan klart konstateras att föräldrarna idag helt saknar förmåga och förutsättningar att tillgodose barnets såväl grundläggande behov som behov av känslomässig tillgänglighet, stimulans, vägledning och stabilitet för att tillförsäkra henne gynnsam hälsa och utveckling. Då föräldrarna inte samtycker till vården är bedömningen att barnet behöver vårdas med stöd av 1 och $2 \$ \S L V U$ då det finns allvarliga brister $i$ omsorgen hos föräldrarna som riskerar att skada hennes hälsa och utveckling. (Utr-C)

I fem fall anförs till stöd för det prognostiserade vårdbehovet att barnet mår och utvecklas bra efter att ha placerats utom hemmet. I samtliga dessa fall framgår att familjehemsföräldrarna anses ha bättre

Katarina Alexius: Prognoser i tvångsvårdsärenden om omsorgssvikt. 
omsorgsförmåga än de biologiska föräldrarna, men det redovisas inte hur barnens påstått positiva utveckling har mätts eller hur orsakerna till den har klarlagts.

Kammarrätten finner att vad som framkommit bl.a. om barnens tandstatus liksom det förhaillandet att barnen har utvecklats positivt när föräldrarna inte har haft vårdnaden om dem visar att omsorgsbristerna medför en påtaglig risk för att barnens hälsa och utveckling skadas. (Kr-A)

Frågan om när skada kan tänkas uppstå behandlas på olika sätt i de skilda fallen. I flertalet av texterna finns beskrivningar som innebär att skada på barnens hälsa och utveckling antingen redan har uppstått eller kan antas inträffa omgående. Ibland är det dock oklart när skada till följd av missförhållandena kan antas uppkomma.

Barnet ställer idag frägor till mamman, som fyraainingar gör, frågor som modern inte alltid kan svara på. Det här försvårar $i$ hög grad barnets förmåga att utveckla kunskapsmässiga och intellektuella färdigheter och förmågor. Detta problem kommer successivt att öka med barnets stigande alder. /.../Socialt har mammans svärigheter börjat bli tydliga för barnet. Barnet märker att hennes mamma kan bete sig på ett avvikande sätt, på exempelvis förskolan. Barnet riskerar här att bli utan en tillfredställande förebild och modell att ta efter $i$ sin sociala utveckling. (Utr-E)

Som redan har nämnts har nästan alla familjerna haft mångårig kontakt med socialtjänsten. I en del utredningar framgår varför barnet nu anses behöva heldygnsvård genom familjehemsplacering efter att tidigare endast ha behövt frivilliga insatser i hemmet. I andra fall går det däremot inte att utläsa varför vårdbehovet på senare tid anses ha ökat. I flertalet ärenden bedöms situationen som akut och omedelbara omhändertaganden har gjorts rörande 19 av de 29 barnen. Rörande 21 barn förs argumentation utifrån att barnet redan har tagit skada av missförhållanden i hemmiljön. I de av dessa fall där det finns en riskbedömning baseras denna på att befintliga skador kan komma att permanentas eller förvärras.

Utredningen visar således att barnet redan visar tecken på att hennes hälsa och utveckling har tagit allvarlig skada. Rätten anser att det är ställt utom rimligt tvivel att barnets tillstånd beror på hennes tidigare och nuvarande hemförhällanden. Det föreligger vidare en påtaglig risk för att detta förhållande ska förvärras ytterligare om barnet inte fär adekvata hjälpinsatser. Det är således ostridigt att barnet har ett hjälpbehov. (Lr-K)

I flertalet av de ovannämnda 21 fallen finns emellertid ingen uttalad prognos utan de närmare effekterna av utebliven vård är underförstådda.

Barnet har under många år farit illa. Han uppvisar stora problem både i hem och skola, han är en rädd och ledsen pojke. Hans problematik idag uppfattas till stor del vara orsakad av hans sociala situation med en mamma som mair psykiskt daligt och har svårt att räcka till. /.../ Barnets behov av 
skydd, omsorg och behandling är omfattande och brådskar. Han har mått dåligt under lång tid och trots långvariga stödinsatser i hemmet har hans situation inte blivit bättre, utan istället försämrats. Det är viktigt att barnet fär rätt hjälp nu medan han också själv är kontaktsökande. Det går fortfarande att nå honom eftersom han beter sig somett yngre barn. (Utr-G)

Preciserade skattningar av styrkan i risken genom beskrivningar av graden av sannolikhet för skador på barnets hälsa och utveckling förekommer inte i vare sig utredningar eller domar. Barnens hemmiljö redovisas emellertid i alla studerade texter genom så pessimistiska beskrivningar att det utifrån dessa måste anses uppenbart att skada på barnets hälsa eller utveckling antingen föreligger eller kommer att uppstå.

Familjens liv är ett kaos och kan inte upplevas på annat sätt av barnen. Familjen är vidare isolerad från omgivningen och barnen kan knappast bjuda hem kamrater frän grannskapet eller skolalförskola. Trots massiva hjälpinsatser framför all frän socialtjänst och Barnhabilitering har insatserna gång efter annan stupat på föräldrarnas bristande förmåga till samarbete och ta till sigråd. (Utr-A)

Redovisningarna av vilken sorts trolig skada eller skaderisk som är aktuell samt vilken omfattning skadan har eller kommer att få, alltså av den eventuella skadans allvar, skiftar mycket mellan ärendena. I många utredningar och domar finns preciserade beskrivningar av en del av de skador som är aktuella. Sådana preciserade skild- ringar rör regelmässigt konkreta problem som bristande skolgång, medicinskt skadlig övervikt, undermålig tandstatus eller motoriska och språkliga utvecklingsförseningar.

I likhet med nämnden anser länsrätten att barnets hälsostatus klart visar att hon har ett särskilt behov av omvårdnad. Därtill har barnets skolgaing inte varit regelbunden och under vissa perioder har hennes frånvaro varit hög. /.../ Rätten anser därför att det föreligger brister i omsorgen om barnet samt att utredningen visar att hennes hälsa och utveckling redan tagit skada. (Lr-M)

I flertalet fall där barnen beskrivs som redan skadade framställs emellertid barnens problematik som främst bestående av bristande självförtroende, nedstämdhet och oförmåga till adekvat social interaktion. Det rör sig alltså om psykosociala skador som beskrivs som orsakade av framför allt en uppväxt med bristande intellektuell stimulans och undermåligt emotionellt bemötande.

Föräldrarnas bristande förmåga har gett och ger barnet, för varje dag som går, allvarliga brister $i$ hans grundläggande omvairdnad och omsorg. Han har svairt med ögonkontakt, han är inåtvänd och tystnar all mer desto sämre han mår. I.../ Barnet är $i$ behov av en lugn, trygg och förutsägbar uppväxtmiljö för att få sina grundläggande behov tillgodosedda. Så har det hittills inte sett ut $i$ hans 13-äriga liv. Hans liv har präglats av oro, bristande grundläggande omsorg, oförutsägbarhet samt bristande vägledning, gränssättning och stimulans

Katarina Alexius: Prognoser i tvångsvårdsärenden om omsorgssvikt. 
vilket gör att han idag saknar de basala förutsättningarna för en gynnsam hälsa och utveckling. (Utr-C)

Rörande 20 av barnen redovisas den påtagliga risken i både utredningar och domar genom beskrivningar av missförhållanden. Bakgrundspåståendena om befintliga problem och misär i hemmiljön kopplas i dessa texter alltså inte till beskrivningar av framtida konsekvenser utan de prognostiserade skadornas närmare art och omfattning är underförstådda.

Rätten finner av dessa omständigheter och vid en samlad bedömning av vad som framkommit $i$ målet styrkt att barnens hemmiljö präglas av konflikter, våld och hot om våld samt att de äldsta barnen fär ta vuxenansvar och även delta $i$ snatterier. Vidare framgår att det saknas rutiner för mailtider och sömn samt att hygien och ordning $i$ hemmet eftersätts. Rätten finner att det på grund av brister i omsorgen finns en påtaglig risk att de fem barnens hälsa eller utveckling skadas. (Lr-D)

\section{Relationen mellan bakgrunds-, prognos- och kunskapspåståenden}

I de studerade utredningarna förs rörande 26 av de 29 barnen fram medicinska eller socialpsykologiska kunskapspåståenden. I ungefär en tredjedel av utredningar knyts kunskapspåståendena till mer eller mindre vetenskapliga eller på annat sätt etablerade referenser. Tydliga sammankopplingar av åberopade kunskaper med förhållandena i det enskilda fallet finns i 5 av de 26 ovan nämnda utredningarna.

Utredaren vill här titta närmare på de sju föräldraförmågor som Kari Killén beskriver $i$ sin bok "Svikna Barn" och som tidigare nämnts i denna text. Utredaren gör bedömningen att modern uppvisar stora brister $i$ de förmågor som anses vara de mest väsentliga och grundläggande för en förälder att klara av. Hon kan ej tillgodose barnets behov av en stabil vardag, förutsägbarhet, àldersadekvat stimulans och lotsning in $i$ samhället. /.../ Då det alltså finns en påtaglig risk för att barnets hälsa och utveckling skadas bör barnet beredas vård med stöd av LVU. (Utr-L)

Det finns inga samband mellan förekomsten av referenser och tydligt återkopplande av kunskapspåståendena till de specifika omständigheterna i fallen. Tvärtom finns i flera ärenden omfattande citat ur mer eller mindre vetenskaplig litteratur utan att det alls framgår varför och på vilket sätt som de aktuella citaten har relevans för den familj som utredningen rör. I en del fall har utredningstexten strukturerats så att vetenskapligt belagda påståenden om riskfaktorer i barns uppväxtmiljö varvas med beskrivningar av hur de aktuella barnen har det. Inte heller i dessa ärenden framgår dock alltid varför den citerade forskningen anses kunna läggas till grund för slutsatser i det enskilda ärendet. Vid en övergripande kategorisering är det $\mathrm{i}$ utredningarna tre olika sorters generaliserande faktapåståenden som förs fram, nämligen generella kunskaper om barns behov, om konsekvenserna för barn av våld inom familjen och om kog- 
nitiva funktionsnedsättningars inverkan på föräldraskap.

Enligt forskare som studerat människor med begåvningsmässiga begränsningar står en person med dessa begränsningars förmåga $i$ stor proportion till om personen har insikt $i$ sitt handikapp och om personen har accepterat handikappet. Begåvningsbegränsningar medför svårigheter att se en skillnad mellan sin egen och andras förmåga eftersom möjligheten att tänka abstrakt är kraftigt reducerad. Barnets föräldrar har tackat nej till föreslagna insatser med hänvisning till att de vare sig är drogmissbrukare eller kriminella samt att deras behov är en fråga om bostad. Det är också vanligt att föräldrar med dessa svårigheter känner sig kränkta av förslag om bistånd till exempel $i$ hemmet eller med sina barn. Barnets moder är av uppfattningen att hon vet hur man ska ta hand om ett barn och att hon inte är i behov av något stöd. (Utr-I)

När exemplifierande beskrivningar av omsorgssvikt i utredningarna läggs till grund för en bedömning av barnets vårdbehov framgår sällan vilka måttstockar som har använts i vårdbehovs- och riskbedömningarna. Innebörden av socialpsykologiskt komplexa begrepp som exempelvis "gränssättning", "känslomässig stabilitet", "omsorg" och "stimulans" redovisas ytterst sällan. Argumentation om förväntningar på föräldrarnas omsorgsförmåga förs regelmässigt utifrån underförstått allmängiltiga referensramar.

Med anledning av den oro som tidigare funnits fick familjen vara kvar sex dagar på
BB, något som är ytterst ovanligt. Fadern har berättat att han tycker att de fick en mycket bra föräldraskola där. Trots det har jourhemmet instruerat både modern och fadern $i$ de mest elementära omsorgsrutinerna då det gäller små barn, bland annat ögonkontakt, matsituationer och lyhördhet inför olika signaler. Som förälder måste man förstå och kunna tillgodose sitt barns behov vid varje tidpunkt, speciellt med ett så litet barn som (namn) är det av största vikt att hans mest elementära behov tillgodoses. Föräldrarna har visat att de inte kan tolka barnets signaler. (Utr-P)

Förekomsten av å ena sida risk- och å andra sidan skyddsfaktorer beskrivs ingående i många av utredningarna. Utvecklingsekologiska synsätt som beskriver samspel mellan olika nivåer i barnets och familjens livssituation saknas däremot helt. En antydan till utvecklingsekologiskt perspektiv kan emellertid sägas finnas i de genomgående förekommande beskrivningarna av barnets och familjens, i flertalet fall dysfunktionella eller obefintliga, "nätverk". Den i utredningarna mest åberopade typen av teoribildning är utvecklingspsykologiska idéer om barns behov av anknytning. I enstaka fall redovisas en bedömning av anknytningens kvalitet i det särskilda fallet.

Forskning visar att en trygg anknytning ger goda förutsättningar för att barn kan utvecklas till en egen självständigt välfungerande person. Oron när barnet blev omhändertaget enligt LVU som spädbarn var att anknytningen mellan mor och barn var svag och att barnet började utveckla copingstrategier. Modern brast i sin förmåga

Katarina Alexius: Prognoser i tvångsvårdsärenden om omsorgssvikt. 
att svara upp på barnets emotionella behov. Av vad som framgår i nuvarande utredning har relationen mellan modern och barnet aldrig stärkts och $i$ dagsläget uppfattas barnets anknytning till modern som otrygg alternativt desorganiserad. (Utr-J, rörande en 11-åring)

I flertalet av utredningarna förs resonemang om bristfällig anknytning i barn/föräldrarelationen utan att vetenskapliga referenser redovisas. Inte i något fall diskuteras hur avvägningen ska hanteras mellan riskerna för att barnet skadas av, å ena sidan, omsorgssvikt och, å andra sidan, anknytningsskador till följd av separation. Tidsramen för och de närmare konsekvenserna av anknytningsbrister beskrivs på ett abstrakt och övergripande sätt.

Det har av flera personer $i$ utredningen framkommit information som tyder på att barnet trots sin ringa ailder uppvisat beteenden som kan tolkas med oro avseende anknytning, kontakt och samspel. Det finns uppenbara samband mellan moderns oförmaga att samspela med barnet och hans något avskärmade beteende. Barnet är $i$ stort behov av en nära och känslomässig anknytning till en eller två vårdgivande personer. Han behöver få sina behov tillgodosedda vad gäller detta för att fortsätta utvecklas på ett hälsosamt sätt. (Utr-N)

I jämförelse med de sociala utredningarna innehåller länsrättdomarna begränsat med text kopplad till generella kunskaper. Endast i en av länsrättsdomarna finns generaliserande kunskapspåståenden med en uttrycklig referens.
I Socialstyrelsens allmänna råd (SOSFS 1997:15 s. 26) anges bl.a. följande under rubriken bristande omsorg. Barn kräver för sin utveckling en miliö som kan ge trygghet, stimulans och känslomässig näring. Ju yngre barnet är desto mer beroende är det av sina föräldrar/vårdare. Även de vuxnas inbördes relation och samarbetsförmåga är viktig för barnen. (Lr-K)

Vidare finns i några underrättsdomar bedömningar, som saknar referenser men som - $\mathrm{i}$ linje med Socialstyrelsens ovan citerade allmänna råd - baseras på socialpsykologiska kunskaper om barn. Domskälen i de elva kammarrättsdomarna saknar i samtliga fall uttryckliga kunskapspåståenden. I nästan alla domskäl från både under- och överinstans finns dock vetenskapligt relaterade uttryckssätt genom att medicinska och socialvetenskapliga begrepp används. Denna vetenskapligt relaterade begreppsanvändning överensstämmer i samtliga fall med den vokabulär som socialnämnden använder i utredningen i ärendet. Så fäster länsrätterna genomgående vikt vid idéer om anknytning när ärendets sociala utredning innefattar anknytningsteoretisk argumentation, utan att någon utgångspunkt för resonemangen utöver socialtjänstens påståenden anges. I flera fall citeras påståenden i utredningen om anknytningsproblematik ordagrant i underinstansens domskäl.

\section{Slutsatser}

Både i utredningarna och i samtliga domskäl är det beskrivningar av nu- och dåtid som läggs till grund för påståenden om att 
det finns en "påtaglig risk" för barnens hälsa och utveckling. Det finns alltså en tydlig relation mellan bakgrunds- och prognospåståenden. Samtliga texter domineras emellertid av redovisningar av de omständigheter som medför att barnens behov inte tillgodoses. Prognoserna är, både i utredningar och i under- och överrättsdomar, summariska och består i många fall av ett lakoniskt påstående om att missförhållandena medför att det finns en "påtaglig risk" för barnets hälsa och utveckling.

Frågan om när skada kan tänkas uppstå beskrivs i både utredningar och domskäl på mycket varierande sätt. Psykosociala skador orsakade av anknytningsproblematik redovisas i regel med en oklar tidsram, medan skada i många andra fall redan anses ha uppstått. Graden av sannolikhet för skada, det vill säga styrkan i risken som gör den "påtaglig", anges inte i något fall genom konkreta skattningar. Av de 29 barnen beskrivs emellertid 21 redan ha skadats och utifrån pessimismen i redogörelserna för hemmiljön framstår graden av sannolikhet för skada i övriga fall genomgående som gränsandes till visshet.

Trots att flertalet av barnen uppges redan ha skador på grund av omsorgssvikt är det i majoriteten av utredningar och domar otydligt beskrivet vad som, om vanvården fortsätter, kommer att hända $\mathrm{i}$ framtiden. Hur allvarliga barnets framtida skador kan antas bli beskrivs alltså sällan. I två tredjedelar av fallen saknas prognostiska konsekvensanalyser.

Texterna i både utredningar och domar fokuserar i dessa fall på skildringar av missförhållanden i hemmiljön i sådan grad att prognoser konstrueras uteslutande genom bakgrundspåståenden. Riskbedömningarna baseras då alltså på redovisningar av problem, vars framtida negativa effekter på barnens hälsa och utveckling är underförstådda. Dessa underförstådda prognoser förstärks ofta genom en språkhantering där vaga påståenden om att barnet "far illa" eller "mår dåligt" kopplas samman med skarpt formulerade beskrivningar av hemmiljön som präglad av kaos och misär. Utifrån de av Högsta förvaltningsdomstolen formulerade kraven på bedömningar av barns behov av tvångsvård är prognoserna således i två tredjedelar av fallen otillräckligt preciserade i såväl utredningar som domar (RA 1995 ref. 46; RÅ 1995 ref. 64; RÅ 2009 ref. 64).

I 26 av de här studerade 29 utredningarna finns påståenden om empiriskt belagda generella förhållanden eller generaliserande teoretiska förklaringsmodeller. Mer eller mindre vetenskapliga referenser för kunskapspåståendena finns dock bara i ungefär en tredjedel av utredningarna. I flertalet utredningar framgår varken varför eller på vilket sätt som kunskapspåståendena är av relevans för de omständigheter som utredningen rör, utan relationen mellan kunskaps-, bakgrunds och prognospåståenden tas för given. Endast i 5 utredningar läggs medicinska eller socialpsykologiska kunskapspåståenden till grund för slutsatser om hur då-, nu- och framtid i det särskilda fallet ska eller bör tolkas. Riskerna för uppkomst eller förstärkning av skador på det utredda barnets hälsa och utveckling beskrivs då alltså genom påståenden om orsakssamband mellan generella kunskaper och bakgrund och prognos i det enskilda fallet. 
I alla utredningar förs mer eller mindre omfattande resonemang baserade på underförstått allmängiltiga referensramar. Exempelvis beskrivs föräldrarnas försummelser ofta utifrån outtalade ideal för föräldrars omsorgsförmåga. Vidare åberopas anknytningsteori frekvent på ett sätt som förutsätter att denna teoris vetenskapliga bas och relevans i det särskilda ärendet är ett vedertaget faktum. Förekomsten av skydds- och stödfaktorer diskuteras i flertalet utredningar, medan bedömningar som utgår från Bronfenbrenners utvecklingsekologiska teori saknas.

Under det att hanteringen av bakgrundsoch prognospåståenden är likartad i utredningar och domar skiljer sig förekomsten av kunskapspåståenden åt genom att domskälen, i motsats till utredningarna, innehåller ytterst begränsat med text som uttrycker generella kunskaper. Domskälen i kammarrättsdomarna saknar helt kunskapspåståenden och i länsrättsdomarna finns endast i ett fall ett kunskapspåstående med referens. Medicinska och socialvetenskapliga begrepp används emellertid frekvent i domskälen. Sättet som dessa begrepp kopplas till familjernas livssituation överensstämmer genomgående med påståenden från socialnämndens sida i respektive ärende. Så anses exempelvis föräldrarna ha otillräckliga adaptiva utvecklingsmöjligheter i samtliga både utredningar och domar. Vad prognostiserandet av föräldrarnas otillräcklighet har baserats på framgår dock endast i tre ärenden. I de övriga 13 fallen är det oklart hur föräldrarnas adaptiva förmågor har klarlagts och bedömts. Detta förhållande innebär att det även är oklart i vilken utsträckning som tidigare stödinsatser har varit relaterade till familjernas specifika behov. Domstolarna godtar emellertid i samtliga fall socialtjänstens uppfattning att föräldrarnas omsorgsförmåga inte kan förbättras. På samma sätt som har påvisats i andra studier ger domstolarna alltså de professionella experterna tolkningsföreträde gentemot enskilda personer (Diesfeld \& Sjöström 2007; Hollander 1985; Jacobsson 2006; Mattsson 2002; McDonnell et al 2000).

\section{Avslutande kommentarer}

Den bristfälliga utformningen av prognoser i två tredjedelar av de studerade utredningarna och domarna kan bero på att de beskrivna missförhållandena är så allvarliga att det anses uppenbart vari riskerna består. BBIC-modellen fokuserar dessutom på insamlande av bakgrundspåståenden utan att ge tydlig vägledning för hur dessa kopplas samma med prognoser och generella kunskaper om behov och risker. Emellertid måste även beaktas att här studerade vårdbehovsbedömningar som rör konsekvensanalyser av omsorgssvikt ofta präglas av osäkerhet. För omsorgssvikt som inte rör främst notoriskt skadliga företeelser som misshandel eller sexuella övergrepp är det helt enkelt svårt att påvisa prognostiska orsakssamband mellan då-, nu- och framtid (Alexius 2011; Backe-Hansen 2001; Claezon 1987; Gillingham 2009; Kaldal 2010; Lagerberg \& Sundelin 2000; Leviner 2011; Lundström 2011; Munro 2008; Sundell et al. 2007; Svensson 2011). Om evidens anses innebära en tillämpning av vetenskap och belagt verkningsfulla interventioner är det 
därför inte självklart att ens tydliga sammankopplingar av bakgrunds-, prognosoch kunskapspåståenden kan anses skapa evidensbaserade vårdbehovsbedömningar (Bergmark et al 2011; Vinnerljung 2006). Tveklöst borde dock kunskaper om barns behov och om risker i barns uppväxtvillkor kunna läggas till grund för konsekvensanalytiska prognoser på ett mer tydligt och strukturerat sätt än vad som förekommer i de här studerade texterna. Det förhållandet att domstolarna regelmässigt baserar sina bedömningar på de kunskapspåståenden som socialnämnden har fört fram innebär dessutom att den granskning av myndighetens bedömningar som förutsätts ske genom domstolsprövningen uteblir.

Konstaterandet av att det i 21 av 29 fall förs argumentation utifrån att barnen redan har tagit skada innebär att socialnämnden, även mot bakgrund av proportionalitetsprincipen, avvaktar påtagligt länge innan ansökan om tvångsvård ges in. Resultatet när det gäller förekomsten av inträffad skada, överensstämmer med tidigare undersökningar av barnavårdsärenden (Leviner 2011; Ponnert 2007). Här presenterade resultat är i och för sig generaliserbara endast för fall av tvångsvård till följd av omsorgssvikt i familjer där någon förälder har kognitiv funktionsnedsättning. Andelen tvångsvårdsfall där familjerna har multiproblem som inkluderar kognitiv nedsättning hos endera föräldern är emellertid hög, ofta 30-40 procent av miljöfallen (Hollander 1985; Llewellyn et al 2003; McConnell et al 2011).

Orsakerna till att tvångsvård av barn ibland äger rum först när skada på deras hälsa och utveckling redan har uppstått torde vara flera. En delförklaring kan vara att det är svårt att redovisa tydliga skadeprognoser och att socialnämnderna helst ansöker om tvångsvård endast i "solklara" fall, det vill säga när barnet redan har tagit skada (Leviner 2011 s 307 f.). Det kan även vara så att utredarna, som i flertalet fall lägger stor vikt vid anknytningsteori, anser att placeringar innebär stora påfrestningar för barn och att det är svårt att bedöma när en invand tillvaro hos en sviktande förälder faktiskt är sämre än ett uppbrott av vardagen genom en placering. ${ }^{4}$ Dessutom kan en tvångsvårdsansökan ofta antas skada samarbetet med familjen i sådan utsträckning att barnet, om ansökan avslås, i sämsta fall är utelämnat till föräldrar som har avsagt sig alla frivilliga insatser (Leviner 2011). I den här studerade ärendetypen kan det vidare av socialnämnden anses komplicerat att hantera avvägningar mellan barns behov ur ett barnperspektiv och funktionsnedsatta föräldrars rätt till familjeliv ur ett likabehandlingsperspektiv. Oavsett bakomliggande orsaker finns det uppenbarligen ett ur barnskyddssynpunkt allvarligt glapp mellan lagstiftningens rättsdogmatiska föreställningsinnehåll och dess faktiska tillämpning.

4 Leviner (2011 s. 306) noterar att det i övervägandena om huruvida ansökan om tvångsvård ska göras eller inte tycks "ingå en bedömning av vilka negativa konsekvenser ett omhändertagande kan innebära för barnet, en slags avvägning mellan 'pest eller kolera". Som har noterats i resultat- och analysavsnittet ovan diskuteras dock inte i någon här studerad social utredning hur riskerna för skada till följd av å ena sidan omsorgssvikt och å andra sidan separation från föräldrarna ska vägas mot varandra.

Katarina Alexius: Prognoser i tvångsvårdsärenden om omsorgssvikt. 


\section{Referenslista}

Alexius, K. (2011). RÅ 2009 ref. 64. Något om tvångsvårdsbedömningar rörande ett barn till en utvecklingsstörd förälder. Nordisk Socialrättslig Tidskrift, 3-4, s. 25-51.

Alexius, K. \& Hollander, A. (2014). Care assessments concerning involuntary removal of children from intellectually disabled parents. Journal of Social Welfare and Family Law. no 3. In print.

Backe-Hansen, E. (2001). Rettferdiggjøring av omsorgsovertakelse. En beslutsteoretisk analyse av barnevernstienstens argumentasjon $i$ en serie typiske saker om småbarn. (Diss.) Olso: Nova.

Bergmark, A., Bergmark, A. \& Lundström, T. (2011). Evidensbaserat socialt arbete: Teori, kritik, praktik. Stockholm: Natur och Kultur.

Bergström, G. \& Boréus, K. (2005). Textens mening och makt. Metodbok i samhällsvetenskaplig text- och diskursanalys, 2:a uppl. Lund: Studentlitteratur.

Bramstång, G. (1964). Förutsättningarna för barnavårdsnämnds ingripande mot asocial ungdom. En studie i socialförvaltningsrättens legalitetsproblem. (Diss.) Lund: Skrifter utgivna av Juridiska fakulteten i Lund.

Claezon, I. (1987). Bättre beslut. En studie av socialsekreterarnas handläggning av omhändertagande av barn. (Diss.) Umeå: Institutionen för socialt arbete.

Diesen, C. och Veloz Roca, A. (2003). Bevisprövning $i$ förvaltningsmål. Bevis 7. Stockholm: Norstedts Juridik.

Diesfeld, K. \& Sjöström, S. (2007). Interpretive Flexibility: Why Doesn't Insight Incite Controversy in Mental Health Law? Behavioral Sciences and the Law, 25, s. 85-101.

Friis, E. (2003). Sociala utredningar om barn. En rättssociologisk studie av lagstiftningens krav, utredningarnas argumentationer och konsekvenser för den enskilde. (Diss.) Lund: Lund studies in sociology of law.

Gillingham, P. (2009). The Use of Assessment Tools in Child Protection: An Ethnomethodological Study. (Diss.) Melbourne: University of Melbourne.
Hollander, A. (1985). Omhändertagande av barn. En studie av barnavårdsmål vid förvaltningsdomstolarna åren 1974, 1977 och 1982. (Diss.) Stockholm: Aktuell Juridik Förlag.

Jacobsson, M. (2006). Terapeutens rätt. Rättslig och terapeutisk logik $i$ domstolsförhandlingar. (Diss.) Umeå: Studier i socialt arbete vid Umeå universitet.

Kaldal, A. (2010). Parallella processer. En rättsvetenskaplig studie av riskbedömningar $i$ vairdnads- och LVU-mål. (Diss.) Stockholm: Jure Förlag AB.

Lagen (1990:52) med särskilda bestämmelser om vård av unga.

Lagerberg, D. \& Sundelin, C. (2000). Risk och prognos $i$ socialt arbete med barn. Forskningsmetoder och resultat. Stockholm: Gothia.

Leviner, P. (2011). Rättsliga dilemman i socialtjänstens barnskyddsarbete. (Diss.) Stockholm: Jure.

Llewellyn, G., McConnell, D. \& Ferronato, L. (2003). Prevalence and outcomes for parents with disabilities and their children in an Australian court sample. Child Abuse \& Neglect, 27 , pp. 235-251.

Lundström, T (2005). Risk, individualisering och social barnavård. Socionomens forskningssupplement, 18, s. 5-14.

Lundström, T. (2011). Om senmodernitet, riskbedömningar och social barnavård. I Höjer, Ingrid och Höjer, Stefan (red.) Familj, vardagsliv och modernitet. En festskrift till Margareta BäckWiklund. Göteborg: Institutionen för socialt arbete, Göteborgs universitet, s. 101-113.

McGaw, S., Scully, T. \& Pritchard, C. (2010). Predicting the unpredictable? Identifying high-risk versus low-risk parents with intellectual disabilities. Child Abuse \& Neglect, 34, pp. 699710.

McConnell, D., Feldman, M., Aunos, M. \& Prasad, N. (2011). Child Maltreatment Investigations Involving Parents With Cognitive Impairments in Canada. Child Maltreatment, 16, pp. 21-32.

McConnell, D., Llewellyn, G. \& Ferronato, L. (2000). Parents with a disability and the NSW 
Children's Court. Sydney: University of Sydney. Mattsson, T. (2002). Barnet och rättsprocessen. Rättssäkerhet, integritetsskydd och autonomi $i$ samband med beslut om tvångsvaird. (Diss.) Lund: Juristförlaget.

Munro, E. (2008). Effective child protection. Los Angeles: Sage Publications.

Peczenik, A. (1995). Vad är rätt? Om demokrati, rättssäkerhet, etik och juridisk argumentation. Göteborg: Norstedts Juridik.

Ponnert, L. (2007). Mellan klient och rättssystem. Tvaingsvård av barn och unga ur socialsekreterares perspektiv. (Diss.) Lund: Socialhögskolan vid Lunds universitet.

Proposition 1989/90:28. Vard $i$ vissa fall av barn och ungdomar.

Proposition 2002/03:53. Stärkt skydd för barn $i$ utsatta situationer m.m.

RÅ 1995 ref. 46.

RÅ 1995 ref. 64.

RÅ 2009 ref. 64.

Socialstyrelsen (2006). Grundbok. Barns behov $i$ centrum (BBIC). Stockholm. Kunskapsöversikt utgiven av Socialstyrelsen, publicerad på www. socialstyrelsen.se.

Socialstyrelsen (2009). Barnets rätt och LVU. Om barnet $i$ rättsprocessen. Stockholm: Socialstyrelsen, publicerad på www.socialstyrelsen.se.

Socialtjänstlagen (2001:453).
SOU 2000:77. Omhändertagen: samhällets ansvar för utsatta barn och unga.

Spratt, T. (2009). Identifying Families with Multiple Problems: Possible Responses from Child and Family Social Work to Current Policy Developments. British Journal of Social Work, 39, pp. 435-450.

Stjernquist, P. och Widerberg, K (1989). Rätten $i$ samhällsbyggandet, 3:e uppl. Stockholm: Norstedts.

Sundell, K., Egelund, T., Andrée Löfholm, C \& Kaunitz, C. (2007). Barnavårdsutredningar - en kunskapsöversikt. 2:a uppl. Stockholm: Gothia.

Svensson, G. (2011). Högsta Förvaltningsdomstolen och LVU. Nordisk Socialrättslig Tidskrift, 3-4, s. 53-94.

Vinnerljung, B. (2006). Fosterhemsvård. Nytta och fördärv. Socialt arbete $i$ kritisk belysning. V. Denvall \& B. Vinnerljung (red.). Stockholm: Natur och kultur.

Watt Boolsen, M. (2007). Kvalitativa analyser: forskningsprocess, människa, samhälle. Malmö: Gleerup.

Östberg, F. (2010). Bedömningar och beslut. Från anmälan till insats $i$ den sociala barnavården. (Diss.) Stockholm: Rapport i socialt arbete, Institutionen för socialt arbete, Stockholms universitet.

Katarina Alexius: Prognoser i tvångsvårdsärenden om omsorgssvikt. 


\section{Summary}

\section{Prognoses in child protection cases concerning neglect}

This study set out to analyse how background context, prognoses and experiencebased knowledge are referred to in child welfare investigations and judgements concerning care orders of neglected children. The texts of social investigations and court judgments in 16 cases concerning parents (30) and their children (29) in two counties in Sweden were analysed as a hermeneutic case study. All cases concerns section 2 in The Care of Young Persons (Special Provisions) Act (1990:52), which states that a care order shall be decided if, due to neglect or some other situations, there is a "palpable risk of detriment" to the child's health or development. The theoretical framework of sociology of law and of normative legalism was used. The study shows that background context, prognoses and experiencebased knowledge seldom are connected in the texts. Background contexts dominate in quantitive terms, while prognoses are vestigial and rarely enunciated as emanating from experience-based knowledge. Instead of describing risk assessments a great many of the descriptions in the texts portray the children as already harmed by neglect. The conclusion of the study is that the sociological conceptions of "a palpable risk" differ a great deal from the legal-theoretical interpretation of the concept. 